\title{
Effect of different levels of water temperature on blood parameters of common carp (Cyprinus carpio)
}

\author{
Sarwar A. Hama Amin and Karwan M. Hama Khan \\ Department of Animal Production, Faculty of Agricultural Sciences, University of Sulaimani, Sulaimani, Iraq
}

Article history

Received: 1 Jun, 2016

Revised: 20 Jul, 2016

Accepted: 25 Jul, 2016

\begin{abstract}
The aim of this study was to find the effect of different water temperatures on haematological parameters of common carp (Cyprinus carpio). A total 16 common carp having mean weight $210.2 \pm 15 \mathrm{gm}$ and length $22 \pm 1 \mathrm{~cm}$ were exposed to three different temperatures $\left(15,25,32\right.$ and $\left.38^{\circ} \mathrm{C}\right)$ for 12 days. The results indicated that red blood cells $(\mathrm{RBC})$, haemoglobin $(\mathrm{Hb})$ and mean corpuscular heamoglobin $(\mathrm{MCH})$ concentration increased significantly $(\mathrm{P}<0.05)$ at $38^{\circ} \mathrm{C}$. A significant drop in white blood count (WBC) and lymphocyte was observed at $15^{\circ} \mathrm{C}$. From the result of the present study, we concluded that at higher temperature $\left(38^{\circ} \mathrm{C}\right)$, there is an increased in $\mathrm{RBC}$ and $\mathrm{Hb}$ concentration and a drop in WBC and lymphocyte count at lower temperature $\left(15^{\circ} \mathrm{C}\right)$.

Keywords: Fish; temperature; blood; common carp
\end{abstract}

To cite this article: SAH Amin, KMH Khan, 2016. Effect of different levels of water temperature on blood parameters of common carp (Cyprinus carpio). Res. Opin. Anim. Vet. Sci., 6(6): 178-180.

\section{Introduction}

Carp can adapt to water temperature as low as $4^{\circ} \mathrm{C}$ and as high as $35^{\circ} \mathrm{C}$. Temperature is known to affect the functional immunology response in ectothermic animals like fishes. Both the habitat and a change of temperature can influence the catalytic properties of enzymes (Klyachko et al., 1998). However, the adaptability of fishes and their ability to exhibit normal activity at extremes of temperature suggest that cellular processes may be maintained at appropriate levels following a period of thermal acclimation or adaptation (Gerlach et al., 1990). In ectothermic organisms, physiological rates can be adjusted to compensate for some changes in temperature. In fish, thermal acclimation is generally determined by blood parameters changes, during which an initial period of thermal stress is followed by a gradual compensation.

When a stable blood parameters level that is consistent between the old and new thermal state is reached, the animal is considered to be fully acclimated (Maricondi et al., 1990) Haematological parameters are increasingly used as indicators of the physiological stress response to endogenous or exogenous changes in fish (Adams, 1990). In Iraq, there is growing interest in the aquaculture of fish species that can survive and grow fast in the warm water. The common carp (Cyprinus carpio) has such characteristics (Houston and Cry, 1974), however; questions on the metabolic traits of the species and its ability to cope with environmental stressors have received little attention.

The objective of the present study was to find the effect of different levels of temperature on haematological parameters of common carp.

\section{Materials and Methods}

The experiment was conducted for 11 days using 16 common carp (Cyprinus carpio). A total 16 common carp (body weight $210.2 \pm 15 \mathrm{~g}$; length $22 \pm 1 \mathrm{~cm}$ ) were

*Corresponding author: Sarwar, Department of Animal Production, Faculty of Agricultural Sciences, University of Sulaimani, Sulaimani, Iraq 
Res. Opin. Anim. Vet. Sci., 2016, 6(6): 178-180.

Table 1: Red blood cell count and their indices in carp fish exposed to different levels of temperature for 12h

\begin{tabular}{lcccc}
\hline Temperature & \multicolumn{4}{c}{ Treatments } \\
\cline { 2 - 5 } & $15^{\circ} \mathrm{C}$ & $25^{\circ} \mathrm{C}($ control) & $32^{\circ} \mathrm{C}$ & $38^{\circ} \mathrm{C}$ \\
\hline $\mathrm{RBC} \times 10^{4} / \mathrm{mm}^{3}$ & $136 \pm 1.9^{\mathrm{c}}$ & $138.5 \pm 3.31^{\mathrm{b}}$ & $144 \pm 2.23^{\mathrm{a}}$ & $146 \pm 5.43^{\mathrm{a}}$ \\
$\mathrm{HCT}(\%)$ & $22.0 \pm 0.8$ & $21.0 \pm 1.1$ & $23.0 \pm 0.7$ & $21.5 \pm 0.6$ \\
$\mathrm{Hb}(\mathrm{g} / \mathrm{dl})$ & $7.7 \pm 0.6^{\mathrm{b}}$ & $7.9 \pm 0.7^{\mathrm{b}}$ & $7.5 \pm 0.7^{\mathrm{b}}$ & $9.0 \pm 0.5^{\mathrm{a}}$ \\
$\mathrm{MCV}(\mathrm{fl})$ & $158 \pm 0.9$ & $155 \pm 0.31$ & $149 \pm 0.43$ & $148 \pm 0.79$ \\
$\mathrm{MCH}(\mathrm{Pg})$ & $55.0 \pm 0.8^{\mathrm{ab}}$ & $53.5 \pm 0.39^{\mathrm{b}}$ & $52.0 \pm 0.55^{\mathrm{b}}$ & $57.2 \pm 0.83^{\mathrm{a}}$ \\
$\mathrm{MCHC}(\mathrm{g} / \mathrm{dl})$ & $34.0 \pm 0.7$ & $33.5 \pm 0.44$ & $33.00 \pm 0.8$ & $37.6 \pm 0.7$ \\
\hline
\end{tabular}

Mean values in a row bearing different superscripts differ significantly $(\mathrm{P}<0.05)$

Table 2: White blood cell count and differential leukocyte count of fish exposed to different temperature for $12 \mathrm{~h}$

\begin{tabular}{lcccc}
\hline Temperature & \multicolumn{4}{c}{ Treatments } \\
\cline { 2 - 5 } & $15^{\circ} \mathrm{C}$ & $25^{\circ} \mathrm{C}($ control) & $32^{\circ} \mathrm{C}$ & $38^{\circ} \mathrm{C}$ \\
\hline WBC $\times 10^{3} / \mathrm{mm}^{3}$ & $12.54 \pm 0.5^{\mathrm{b}}$ & $13.4 \pm 0.45^{\mathrm{ab}}$ & $13.2 \pm 5.43^{\mathrm{ab}}$ & $14.6 \pm 0.43^{\mathrm{a}}$ \\
Lymphocytes $/ \mathrm{mm}^{3}$ & $68.8 \pm 4.8^{\mathrm{b}}$ & $76 \pm 3.4^{\mathrm{a}}$ & $78 \pm 3.7^{\mathrm{a}}$ & $78.4 \pm 4.4^{\mathrm{a}}$ \\
Moncytes $/ \mathrm{mm}^{3}$ & $1 \pm 0.4$ & 0.00 & 0.00 & $1 \pm 0.6$ \\
Neutrophils $/ \mathrm{mm}^{3}$ & $17.3 \pm 2$ & $14 \pm 1.31$ & $18 \pm 1.8$ & $16 \pm 1.79$ \\
Eosinophils $/ \mathrm{mm}^{3}$ & $3 \pm 1.3$ & $2 \pm 1.2$ & $3 \pm 1.5 .00$ & $4 \pm 2.00$ \\
\hline
\end{tabular}

Mean values in a row bearing different superscripts differ significantly $(\mathrm{P}<0.05)$

distributed evenly into four glass basins, controlled by static systems and cleaned by suction daily. Approximately, $10 \%$ of the water in the tanks was replaced daily. The temperature was then changed to the target temperature of 15,32 , or $38^{\circ} \mathrm{C}$ over a period of $12 \mathrm{~h}$, whereas the control group was kept at $25^{\circ} \mathrm{C}$. Fish were maintained at these four temperatures for 12 $\mathrm{h}$ and then sampled. Consequently, the chosen temperature ranges were nonlethal but close to the thermal limits of this species. Each glass basin was stocked with four fish and fed twice a day. Fish in the experiment were fed a commercial ration at the rate $4 \%$ of body weight.

\section{Blood component analysis}

At the end of the experiment, blood samples $(0.05$ $\mathrm{ml}$ ) were quickly collected from the caudal vein of immobilized common carp without anaesthesia. Netting and blood sampling did not take more than 30 seconds. Blood samples were immediately mixed with ethylenediamine tetraacetic acid (EDTA). Blood samples were analyzed for different haematological parameters as described by Benjamin (1978).

Data was analyzed as analysis of variance (ANOVA). The significant difference was determined by Tukey test. P value less than 0.05 was considered as statistically significant.

\section{Results and Discussion}

Low dietary protein, insufficient food and non optimal water temperature have been discovered for the inhibition of fish growth (Fine et al., 1996). The result of the present study indicated that red blood cell count (RBC), haemoglobin ( $\mathrm{Hb})$ and mean corpuscular haemoglobin $(\mathrm{MCH})$ concentration increased significantly $(\mathrm{P}<0.05)$ at $38^{\circ} \mathrm{C}$ (Table 1$)$. Haematological indices are very sensitivity for different chemicals and environmental factors (Vosylienë, 1999). Clinical analysis of haematology, however, is not often used in fish medicine. Physiological changes at different temperatures can be affected by the quality of the water (Van, 1986). The increased RBC count in the present study at higher temperature may be due to the contraction of the spleen resulting in an increased circulating blood volume (Langston et al., 2002). The increased blood $\mathrm{Hb}$ and MCHC may be due to the increased number of RBC.

In the current study, there was a drop in the total leukocyte count and lymphocyte percentage at $15^{\circ} \mathrm{C}$. A drop in blood leukocytes at $8^{\circ} \mathrm{C}$ was observed in tench, hybrid striped bass and gilthead sea bream (Collazos et al. 1993; Hrubec et al. 1997; Sala-Rabanal et al., 2003). Acute stress has been linked to decline in the number of thrombocytes and lymphocytes redirecting them towards kidney and thymus (Sala-Rabanal et al., 2003).

\section{Conclusion}

From the results of the present study, we observed an increased in $\mathrm{RBC}$ and $\mathrm{Hb}$ concentration at higher temperature $\left(38^{\circ} \mathrm{C}\right)$ and a drop in WBC and lymphocyte count at lower temperature $\left(15^{\circ} \mathrm{C}\right)$ in common carp.

\section{References}

Adams SM (1990) Biological Indicators of stress in Fish". American Fisheries society, Bethesda, MD, pp: $1-8$.

Benjamin MN (1978) Outline of Veterinary Clinical Pathology. University Press. Iowa, USA. pp: 229232.

Collazos ME, Barriga C, De-Sande F, Ortega E (1993) Seasonal variations and influence of gender on several haematological parameters in the cyprinid 
fish Tinca tinca. Actas del IV Congreso Nacional de Acuicultura. Cervino, A., Landin. A., De-Coo, A. Guerra, A. Torre, M. Eds. Pontevedra, Spain. pp: $173-178$.

Fine M, Zilberg D, Cohen Z, Degani G, Moav B, Gertler A (1996) The effect of dietary protein level, water temperature and growth hormone administration on growth and metabolism in the common carp (Cyprinus carpio). Comp Biochem Physiol 114: 35-42.

Gerlach G, turay 1, Mailik K, Lida J, Scutt A Goldspink G (1990) The mechanisms of seasonal temperature acclimation in carp: a combined physiological and molecular biology approach. Am J Physiol 259: R237-R244.

Haider G (1973) Comparative studies of blood morphology and haemopoiesis of some teleost. Observations on cells of the red series. J Zool 179: 355-383.

Houston AH, Cry D (1974) Thermoacclinatory variation in heamoglobin system of gold fish and rainbow trout. J Exp Biol 61: 445 -461.

Hrubec TC, Smith SA, Robertson JL (1997) Agerelated changes in hematology and plasma chemistry values of hybrid striped bass (Morone chrysops $\times$ Morone saxatilis). Vet Clin Pathol 30: $8-15$.

Klyachko OS, Ozernyuk ND (1998) Functional and structural properties of lactate dehydrogenase form embryos of different fishes". Comp Biochem Physiol 119: 77-80.

Maricondi-Massari M, Kalinin AL, Glass ML, Rantin FT (1998) The effects of temperature on oxygen uptake, gill ventilation and ECG waveforms in the Nile tilapia, orechromis niloticus. J Thermal Biol 23: 283-290.

Sala-Rabanal M, Sanchez J, Ibarz A, Fernández-Borràs J, Blasco J, Gallardo MA (2003) Effects of low temperatures and fasting on hematology and plasma composition of gilthead sea bream ( Sparus aurata). Fish Physiol Biochem 29: 105-115.

Van Vuren JHJ (1986) The effects of toxicants on the haematology of Labeo umbratus (Teleostei; cyprinidae). Comp Biochem Physiol 83C: 155- 159.

Vosylienë MZ (1999) The effect of heavy metal mixture on haematological parameters of rainbow trout. Heavy metals in environment. An integrated approach. (ed. DA Lovejoy). pp: 295-298. 